\title{
Uusioersily
}

\section{Creating liminal spaces of collective possibility in divided societies: building and burning the Temple}

McDowell, S., \& Crooke, E. (2019). Creating liminal spaces of collective possibility in divided societies: building and burning the Temple. Cultural Geographies, 26(3), 323-339. https://doi.org/10.1177/1474474018817791

Link to publication record in Ulster University Research Portal

\author{
Published in: \\ Cultural Geographies
}

Publication Status:

Published (in print/issue): 01/07/2019

DOI:

$10.1177 / 1474474018817791$

\section{Document Version}

Author Accepted version

\section{General rights}

Copyright for the publications made accessible via Ulster University's Research Portal is retained by the author(s) and / or other copyright owners and it is a condition of accessing these publications that users recognise and abide by the legal requirements associated with these rights.

\section{Take down policy}

The Research Portal is Ulster University's institutional repository that provides access to Ulster's research outputs. Every effort has been made to ensure that content in the Research Portal does not infringe any person's rights, or applicable UK laws. If you discover content in the Research Portal that you believe breaches copyright or violates any law, please contact pure-support@ulster.ac.uk. 


\section{Creating liminal spaces of collective possibility in divided societies: Building and burning the Temple}

\section{Sara McDowell and Elizabeth Crooke}

\section{Introduction}

Representational practices aimed at navigating difficult pasts in public space presents a formidable and sometimes insurmountable challenge in transitional and/or divided societies. ${ }^{1}$ This is evident in Northern Ireland where dealing with the past has often been regarded as partisan, territorial, and at points, deeply antagonistic. ${ }^{2}$ In was into this setting that in 2015 the acclaimed American sculptor David Best was invited to recreate one of his Temples, typically found in the Nevada Desert at the counter culture festival Burning Man. The Temple was erected on a hilltop overlooking the 'wounded' 3 city of Derry/Londonderry, a city in transition that is struggling to reverse an engrained geography of division and navigate a commemorative landscape documenting a divided and contested past. Enlisting help from cross sections of the local community, Best and his team set about creating what James Young might term a 'counter-monument', a memorial that would prove almost the antithesis to what came before. ${ }^{4}$ The memorials Young observed in Germany in the 1990s marked a departure in what he described as 'cherished memorial conventions'. Their aim was 'not to console but to provoke; not to remain fixed but to change; not to be everlasting but to disappear; not to be ignored by its passers-by but to demand interaction; not to remain pristine but to invite its own violation and desecration; not to accept graciously the burden of memory but to throw it back... 5

The Temple was ambitious. The intricately carved $72 \mathrm{ft}$ post and beam pyramid-like plywood structure quickly altered the city's skyline. Supported by 20 columns with eaves projecting over an ornate arcade and obelisk, it offered, according to architecture critic Phineas Harper, an alternative aesthetic that challenged 'Western architecture's frigid relationship with decoration' ${ }^{6}$ Over the course of a week in March, an unprecedented 60,000 people visited the ephemeral structure and helped create a lieux de memoire that they knew would be destroyed. ${ }^{7}$ They left messages, pictures and other artefacts in remembrance of their loved ones, and as the sun set on Saturday evening they watched as it burned to the ground, leaving no trace.

Till suggests that 'more attention needs to be paid to artistic interventions ... that advance the difficult work of memory in wounded cities marked by particularly violent and difficult pasts' ${ }^{8}$ In cities that are emerging from violent or challenging pasts 'memory-work signifies more than past and ongoing resistance to the status quo'. ${ }^{9}$ Rather she argues it offers an opportunity to readdress social justice issues and, on some level, to provide a space for place-based care. Responses to the Temple in Derry/Londonderry indicate that this particular intervention, despite its transitory nature, contributed to healing on some level. Best's Temple allowed individuals to come to terms with the past, or engage with traumatic and painful memories, in a way that was not necessarily wed to the (spatial) politics of the present. The ambiguity of the liminal space created by the project challenged the physicality and very structured messages embedded within many of the city's murals, monuments and museums. ${ }^{10}$

This paper not only responds to Till's call for a more nuanced critique of the role of artistic interventions, but also pushes the debate further by exploring how the creation of liminal spaces within deeply divided societies permit unprecedented shared opportunities for reflection, representation and ownership. In doing so, the paper makes two important contributions. First, it documents how artistic interventions can provide an alternative means to collectively remember that is welcomed in societies ruptured by violence. Drawing on Till's seminal concepts of 'wounded cities,' 'place-based care' and 'memory-work', this paper uses the case study of Derry/Londonderry to tease out how Best's 
Temple addressed 'open wounds' in a city marred by protracted ethno-nationalist conflict. Second, by framing liminal space as a potentially important and overlooked tool, not only in peacebuilding but in societies dealing with deep-rooted divisions, the paper engages in a conceptualisation of the liminality embedded within the Temple. We suggest that interventions can provide possibilities to cut through not only the pain of the past as observed by Till in her study of wounded cities, but also division in segregated societies in new ways, if only momentarily. It is argued here that the concept of liminality might provide novel ways of thinking about the twin processes of remembrance and peacebuilding in wounded cities.

\section{Research design}

The data for this paper was collated through employing a methodological approach that consisted of ethnography and social media data analysis. An ethnographic approach ${ }^{11}$ comprising participant observation was critical to gain a sense of how people experienced and navigated the Temple. We participated not just as academics and researchers, but also as residents of the city wanting to be a part of 'whatever was happening on the hill'. Not knowing what to expect or 'do' whilst there, we visited the Temple throughout the week of the build, recording our observations, reading the inscriptions, and capturing the structure's evolution. We parked our cars at the bottom of the hill and alongside thousands of others made the short walk to the top. We brought our young families and watched them play amid the structure. We visited with relatives, many of whom had lived through the worst years of violence in the city. We watched as some people stood silently in awe while others scribbled messages on small pieces of plywood. We left our own messages and took some time to reflect on what the Temple meant to us.

It became clear that public participation was at the crux of each stage of the Temple - funding the project, building the structure, visiting, inscribing and adding objects. Rather than static, this memorial structure was ever evolving - it came to life through people's engagement and within seven days came to a dramatic conclusion with the final burn. This participation was further extended via social media, when a virtual community was formed online in which people shared their experiences. To unpack some of the ways in which participants experienced the site, we analyzed data from social media platforms. An analysis of Twitter, online blogs, and the Temple's own website, provided an insight into how some participants shared their experiences online. Castells' seminal work on networks argues that contemporary social and political movements are interacting in very different ways in the digital age, and these kinds of interactions are challenging existing power structures. ${ }^{12}$ There is a growing consensus that digital technologies and social media platforms are producing new forms of political participation and mobilization. Bennett agrees, suggesting that in providing new interactive and largely uncensored spaces to exchange views, there is the potential for a more diverse mobilization of people to drive and shape our understanding. ${ }^{13}$ Because of social media people are no longer 'passive observers' but, as Loader and Mercea observe, are actively 'challenging discourses, sharing alternative perspectives and publishing their own opinions'. ${ }^{14}$ The volume of online activity suggests that the initiative was able to create, if only fleetingly, a virtual community based around responses to the Temple. ${ }^{15}$

Our discussion is divided into three parts. The first part of the paper introduces the theoretical framework, conceptualizing the liminality of Best's Temples and exploring liminal space as a tool for addressing difficult or traumatic memories in contested spaces. In the second section, drawing on Till's concept of a wounded city we consider the nature of space and place within Derry/Londonderry and discuss some of the challenges facing Best and his team. In the remainder of the paper we tease out the specific characteristics of the Temple's liminality. We examine the ways in which it differs to 
more traditional forms of memory-work and overcame what Johnson refers to as the memetic challenges of 'confronting the act of publicly reconciling individual and collective remembrances' of the past in a deeply divided society attempting to transition from violent conflict. ${ }^{16}$

\section{Conceptualizing liminal spaces of possibility, interaction and memory: Best's Temples}

The word liminal derives from the Latin 'Limen', which means threshold. It is used to describe an ambiguous, transitional state ${ }^{17}$ and denotes a space of possibility usually employed in ritualism. Liminal spaces are, according to Turner, 'in between, set aside, or separate contexts where the rules for acting or interpreting meaning are different from the rest of life'. ${ }^{18}$ For Schirch they are places and times 'that create an opening or give permission to try out new or alternative ways of interacting'. ${ }^{19}$ Geographers, as Matthews notes, have employed liminality as a conceptual approach to understanding the dynamics of a range of spaces from the street, prisons and cyberspace to borders and schools. ${ }^{20}$ Yet its conceptualization as a space that dichotomously permits remembering and forgetting that enables a degree of catharsis, is often overlooked; as is its potential application to peacebuilding or advancing memory-work in divided societies. ${ }^{21}$

Liminality is in many ways at the crux of at the Burning Man festival although it is not explicitly conceptualized as such. The festival, which culminates in a final burn, began as a small gathering of around 35 people in San Francisco in the summer of 1986. Founders Larry Harvey and Jerry James, alongside a group of friends, constructed a wooden figure and burned it at the summer solstice. It became an annual gathering and in 1990 moved to Black Rock in the Nevada Desert to accommodate its growing number of followers. ${ }^{22}$ The burn continued as a central feature of the festival, marking the end of the festival and offering a form of symbolic closure for its participants. For Bottorff, Burning Man has become one of the biggest 'transformational' festivals in the world. ${ }^{23}$ Participants go there anticipating change. Part of its appeal is its difference from traditional or religious environments in that little or no explicit spiritual or psychological guidance is offered and there are few formalized rites and rituals. ${ }^{24}$ Rather, the search for meaning and healing relies upon self-direction and peer support that can only occur in, as we suggest, a liminal space. Burning Man quickly became a ritualized gathering during which participants entered an ambiguous space searching for meaning. ${ }^{25}$

The sculptor David Best began contributing to Burning Man in 2000 when, after the loss of a close friend in the weeks before the festival, he encouraged participation in a more direct and emotive level. He introduced a new effigy, replacing the original structure with a large wooden 'Temple'. ${ }^{26}$ He asked participants to bring with them memories of their own individual losses and also artefacts that reminded them of someone they had loved and lost. He was, as Van Meter attests, asking people to 'drag their heaviest burdens to a hostile and remote location, drop them off, and watch them burn' ${ }^{27}$ When describing his own work in an interview for the San Francisco Museum of Modern Art, Best talked about how important it is to create something so beautiful and ornate for participants that 'you're prepared to give up what's been haunting you your whole life'. ${ }^{28}$ Memory and forgetting are juxtaposed at Burning Man. Participants create a living and dynamic archive that will only exist for a short period of time. They engage in a process that they know will have some sort of finality and contribute to a process of closure.

Bateman employs a psychological lens to critique the ritualism and mourning process that takes place at Burning Man each year. She suggests that while losing a loved one is a unique and personal experience, the grieving process occasions a series of 'collective themes which may be operative in the rituals enacted at the Temples'. ${ }^{29}$ The loss of a loved one triggers a series of common processes of grieving and recovery (irrespective of how they died). The physical inaccessibility instigates an 
overwhelming need to connect or to recover something - an object, a memory, a tangible reminder of their dead. When the hope of reconnecting dissipates, despair emerges and disorganisation sets in. Mourners feel the totality of the loss, leading to reorganisation, which is the final stage of mourning. These processes are widely accepted not just by psychologists but also by object relations theorists (who refer to organisation, disorganisation and reorganisation ${ }^{30}$ ) and psychoanalytic theorists (who present this as cathexis, decathexis and eventually recathexis ${ }^{31}$ ). The liminality of the Temple in many ways facilitates points in this journey: it encourages participants to recover something to represent the life of the deceased - an object or a memory - and bring that object to a specific space (the structure). At that moment these are testimonial objects - a means to tell a personal story; they can also be considered an opportunity to contemplate and memorialise loss. ${ }^{32}$ This is the organisation or cathexis stage of the process. The disorganisation or decathexis takes place during the final burn. The period after the final burn permits the final stage, which Bateman calls reorganisation. The process of destruction by fire becomes empowering, which enables a period of possibility, 'fire represents a mesmerising but disturbing ambiguity. Fire destroys, as well as fertilises, as a forest blackens sets up for re-growth'. ${ }^{33}$

While the experience of the Temple at Burning Man is rooted in liminality, it is not devoid of a cultural framework or a degree of control/structure. It occurs annually in a specific place and is part of a ticketed event. Work on the design begins long before the festival takes place. There is planning, organisation and choreography-the experience and space however is entirely liminal. The approach and aspirations of the project that was to be reimagined in Derry therefore was the outcome of years of work by Best and the project methods, embedded in community engagement practice, were well established. Nevertheless, for participants the Temple experience is fluid and personal. As a completely novel contribution to the memorial landscape in Derry, there would be no predetermined way of interpreting the site or experiencing it. The liminality derives from the ways in which participants are free to interpret its meaning and engage in a process. Participants must draw upon what Rodriguez calls a 'radical self-reliance'. ${ }^{34}$ This is not a deterrent; participants engage with the Temple precisely because of its liminality, its ambiguity, and transitional nature. The appeal of a liminal space therefore lies in its hybrid and fluid nature. It can be a malleable space with no fixed or structured meaning. But how exactly might this play out in a society fraught not only with contested spatial politics, but with divergent interpretations of the past?

\section{Juxtaposing the symbols of division in a wounded city: Bringing the Temple to Derry/London- derry}

Till defines wounded cities as 'that have in some way been 'harmed and structured' by multiple forms of violence over time, oftentimes through or by the state. ${ }^{35}$ Such cities are not ruptured through 'one singular external or outside event' but by pervasive and often continuous forms of violence that inform 'social and spatial relations... and expectations of what might be considered normal'. She suggests that just as individuals are impacted by trauma, displacement and devastation, so too are cities and their inhabitants. ${ }^{36} \mathrm{With}$ a deep-rooted history of conquest, displacement and internal division, Derry/Londonderry can be conceptualized as a wounded city. Derry was 'settled' by the London companies in the $1600 \mathrm{~s}^{37}$ thanks to its strategic positioning in the Northwest corner of Ireland on the banks of the River Foyle which provided excellent access to the open sea and related opportunities for trade and defence. The London companies constructed the city's walls providing a home for English and Scottish settlers who had begun arriving in Ireland as part of the controversial plantation of Ulster. At that time 'Derry' became 'Londonderry' and the seeds of ethno-nationalist division were sown. Later the city was besieged in 1689 during the fractious religious wars in Europe 
as its Protestant residents held off the advancing armies of Catholic King James. The city became increasingly segregated along religious lines following the partition of the island of Ireland in 1921, and the economic and political disempowerment of the growing Catholic population intensified.

The polarization of the city was reflected in its physical geography. Divided by the river running through the heart of the city, the West bank was predominantly Catholic (with one sizeable Protestant community living within the walls in the Fountain estate) and the East bank (known as 'the Waterside') was predominantly Protestant. As the sectarian violence of the Troubles unfolded, the city imploded. Its streets and buildings incurred the scars of shootings, riots and bombings and its landscape grew increasingly militarized, from the road blocks and burnt out cars policed by paramilitaries during the early 1970s, to the series of British Army checkpoints and watchtowers inserted into the landscape across the city to monitor the population. The shooting by the British Army of 13 unarmed Catholic civilians in 1972 during a civil rights march transformed the conflict and swelled the membership of Republican paramilitary groups, fuelling more violence. ${ }^{38}$ This particular event has had important implications both for the city's trajectory and its psyche: continuing to constitute an 'open wound'. Distrust in the State apparatus intensified and ethno-nationalist divisions were concretised. As sectarian violence continued, the Fountain's Protestant residents flocked away from the West Bank of the city, consolidating a divide that has yet to ,diminish despite a protracted period of peacebuilding.

From the outset, the Temple was conceptualized as a unique contribution to the 'recovery landscape' of 'post-conflict' Derry/Londonderry. The leadership team at Artichoke, the arts company that had lobbied Best to bring the Temple to Derry, believed that its transformative power could be harnessed in the city through manipulating some of the commemorative symbols and performative practices that are often used to divide and separate people. It was in part referring to the frequent use of fire in the region to commemorate prominent political, cultural or religious events. 'Large-scale fire based public events' such as the creation of bonfires and the burning of effigies are as Santino notes a 'staple feature of traditional celebratory life in Northern Ireland'. ${ }^{39}$ These annual commemorations delineate and demarcate difference and have spilled over into violent confrontations. They are, according to Jarman, ${ }^{40}$ largely single-identity enactments that are not intended to bridge community divisions.

Bonfires have traditionally been a divisive cultural tradition/practice and are used largely to mark events that resonate with the diametrically opposed territorial ideologies of Ulster Unionism/Loyalism and Irish Nationalism/Republicanism. A key date for Loyalists and Unionists is the eleventh night (July 11) bonfires that mark the beginning of the annual Battle of the Boyne commemorations. This commemorates the 1690 victory of the Protestant King William of Orange over the Catholic King James II. Effigies of key opposing political figures or the Irish national flag are often placed on top of the bonfire and burned. The antagonistic nature of bonfires is observed by Hocking who posits 'few dates on Northern Ireland's calendar are more fraught than the night of July 11, when loyalists across the still-divided province light towering bonfire pyres bedecked in anti-Catholic, anti-Irish imagery'. ${ }^{41}$

Nationalists and Republicans also use bonfires and burn political paraphernalia and flags to commemorate key dates of political and/or religious significance. Each August the anniversary of internment is remembered with bonfires and, more recently, by contentious parades. Internment was a controversial policy enacted by the Unionist government in 1971 to intern suspected paramilitaries without charge to deal with the escalating political crisis across Northern Ireland. This policy was met with acute levels of violence and widely criticized as in its first few months it was applied solely to young Catholic men with no involvement in Republican violence. In Derry the date of the antiinternment bonfires in August coincide with a parade that is celebrated by Unionists to mark the Re- 
lief of Derry in 1689 following a siege that lasted 105 days which have traditionally led to heightened tensions and sometimes violence across the city. ${ }^{42}$ For Santino the annual summer bonfire celebrations celebrated by 'both sides', are very 'clearly and manifestly political and overtly sectarian events'.

It was set against this complex context of memory-work that Best was invited to recreate his Temple. Artichoke aimed to challenge the bonfire tradition: 'We wanted to turn the logic of bonfires on its head. We wanted to bring people into the same physical space and share something that would normally divide them'. News of the initiative was met with apprehension in some quarters. Some religious figures were initially opposed to the Temple, questioning the rationale for employing fire as a tool for good, asking how it might have a productive outcome in a city where it has always been synonymous with hating the 'other'. ${ }^{43}$ This sentiment was not confined to religious figures. 'Burning a 75 foot-tall pagan temple to bring people together' as the New York Times tweeted 'seemed, well, mad'. Some members of the public shared this apprehension. Comments exchanged online included: 'Just what they need-another bonfire!; another remarked 'Cool idea, but no doubt some arsehole will try and ruin it by putting flags on it'; in reply it was suggested 'Sure it's not a proper bonfire without tricolours and Sinn Féin election posters'. ${ }^{44}$ The organisers were aware of the symbolism of the Temple and its reconstruction somewhere like Derry; as Best noted: 'It's kind of like a bonfire only it's based on forgiveness'. 45 'A bonfire of hope', as one participant noted, in a segregated city. ${ }^{46}$

\section{Navigating open wounds}

In 'In Praise of Forgetting' David Rieff warns of the many political and social risks that remembrance carries with it. ${ }^{47}$ In cases when 'collective memory condemns communities to feel the pain of their historical wounds and the bitterness of their historical grievances it is not the duty to remember, but a duty to forget, that should be honoured'. ${ }^{48}$ Remembering in Derry/Londonderry has been a painful process and fraught with difficulty. ${ }^{49}$ In a landscape saturated with open wounds, healing has, at many points, been an elusive goal. The Temple was an experiment, an audacious risk that would offer a radical departure from many of the existing patterns of commemoration and performance not only in the city, but across Northern Ireland.

In their analysis of memory-work, Graham and Whelan present the commemoration of conflict in public space in the region as contested, separate (perhaps even ghettoized), and highly gendered with public monuments and murals focusing largely on male narratives of the past - resulting in an intervention that they suggest is most often 'grimly divisive'. ${ }^{50}$ Johnson's reading of the commemoration of the Omagh bombing by Republican paramilitaries, which killed 29 people in 1998, is more hopeful. She identified a 'politics of hope' in that people without a shared communal history came together to find a public space to represent their shared loss after the tragedy. Yet even this memorial garden, fraught with difficulty in its imagining, has been subject to periodic acts of violence and vandalism. Marschall's analysis of memory-work in post-apartheid South Africa points to the instability of meaning within memorial landscapes in public space. Their meaning evolves with each encounter and as such, they can become the focus of either acceptance or resistance. ${ }^{51}$ In Northern Ireland many of these more traditional methods of commemoration have become entrenched, focused around partisan practices that are themselves now becoming an extension of the conflict. ${ }^{52}$ We see this not only on the streets of segregated communities in Northern Ireland, but in the public spaces of towns and cities across the U.S; as divided societies grapple with how best to navigate difficult and challenging pasts in public space. ${ }^{53}$ Such landscapes arguably provide little opportunity for creative ways of thinking about and marking the past in public places that is more relevant to a greater diversity of people, attitudes and interpretations. 
In the building of an impressive structure, carrying text that recorded the life of the deceased and the thoughts of the living, then publicly displayed, the Temple would bear some resemblance to these more traditional forms of representing conflict in the city. However, Best managed to create a space which struck a chord with tens of thousands of people (in a city of 100,000). Over the course of one week, the Temple created and contained a liminal space of possibility, and in doing offered a moment of healing. Through its liminality the Temple countered some of the aspects of memorialisation that have occasioned conflict. It is to these aspects and characteristics that the paper now turns.

\section{Redistributing ownership: Engaging stakeholders and widening participation}

McEvoy and Conway writing about the politicisation of the dead in divided societies, suggest that amid efforts to appropriate loss for the assertion of ideology or action, death can become 'de-individualised'. ${ }^{54}$ This invariably leads to a lack of ownership where families and friends lose the right to commemorate their loved ones. When the political stakes are high, as they so often are in divided societies, commemoration becomes an exclusive practice, limiting the scope for shared remembrance. For Gillis, commemorative activity is 'social and political, for it involves the co-ordination of individual or group memorials whose results may appear consensual when they are in fact the product of intense struggle and in some instances annihilation' ${ }^{55}$ Unlike many of the monuments and commemorative murals in working-class neighbourhoods in the city which have been constructed for the most part by combatant organisations or groups sympathetic to a particular cause or narrative, Best's Temple was a project that invested in and engaged with multiple stakeholders and audiences. From its inception, the initiative was crowd-led and crowd-sourced; it was an artefact that was created by a cross-section of the city's population and one that a huge number of people interacted with.

As embedded as the eventual project was in community arts, it was enabled by key agencies in Northern Ireland, including the Arts Council and the Northern Ireland Community Relations Council, the project was placed in the centre the official processes of peace building. Launching the Kickstarter campaign to bring the Temple to the city, an Arts Council spokesperson described it as an 'epic' peacemaking art project. ${ }^{56}$ Via a kickstart fund, which was crucial to the project's viability, over 600 investors raised $£ 36,000$ to fund the materials for the structure while volunteers and stewards helped bring the Temple alive. One local man remarked 'while the concept belongs to David Best-an intense, inspirational character with a huge vision of compassion and creativity....the Temple will belong to the City. At its heart, the Temple will be created by and for the people of Derry' ${ }^{57}$

Best and the Artichoke team recognized the importance of engaging with people from across the religious and ethno-nationalist divide. When they arrived in the city to begin the build, they enlisted the help of the city's youth from different community backgrounds. Harland's 2011 study of young men in Northern Ireland found that although born after the 1994/5 ceasefires, many 'spoke articulately of how the Troubles were still remembered and glorified in their communities'. ${ }^{8}$ This generation was also aware that bonfires and contentious parades in their towns and cities 'reinforced community divisions and fuelled hatred'. In a further study, Harland and McCready reported that many young people in working-class communities 'felt disconnected from local initiatives and believed they were regularly perceived as problems as opposed to resources' ${ }^{59}$ Confronting these realities, the Temple team convened workshops in some the city's most deprived communities (who had also experienced acute levels of violence during the Troubles) and asked for help designing and cutting wooden lanterns that would be used on the night of the burn. With the help of a local tech start-up, Best and his team encouraged young people to complete training that allowed them to design the panels that marked the perimeter of the Temple. ${ }^{60}$ They also reached out to schools - the future generations of the city. Workshops were convened in 20 of the city's schools where children had the opportunity to 
produce paper designs that were reproduced and added to the design. The range of involvement from the community underscored the sense of collective ownership for the project, which fed into the overwhelmingly positive response.

\section{Deterritorialising place? Creating a liminal, shared space}

Till suggests that a 'place-based ethics of care' within wounded cities can create more socially just cities with differentiated and active forms of belonging. She describes such practices as rooted in memory-work, stating they can help underpin a sense of multigenerational rights in a city. With the Temple, the organisers wanted to tap into this idea of creating a safe place, albeit a liminal and temporary one, that would transcend boundaries across multiple scales. They wanted the Temple to foster 'peace, love, reconciliation, mediation and spiritual renewal and promote an ethics of care across the community. It was hoped that those very values would lead to a 'shared space' to which people would bring 'offerings, mementoes and memories and try to ditch some of the stuff from the past, let go in order to move on'. One of the co-founders of the Burning Man festival, shared this hope suggesting that the city had the potential to reveal 'one of the most potent effects of the temple: unification'. She asked: 'Can Temple bring people together? Can people who feel different come together there and have a moment where they feel the same? Those are the questions Temple can answer, and that's why its ashes always represent a beginning'. ${ }^{61}$ These words further underline both the exploratory and risky nature of the initiative as well as its far-reaching aspirations.

The territorial nature of space in the city made finding a suitable site for the Temple challenging. Best and his team decided to build the Temple in an 'open' space on a hilltop overlooking the entire city. Known locally as 'Kelly's fields', it was at one time, according to Harper, a popular spot for family picnics. ${ }^{62}$ However, the outbreak of violence in the city and the area's proximity to a Nationalist/Republican neighbourhood transformed its inclusivity. Access became difficult and it was no longer used. Justifying the decision to build the Temple there, the organisers noted: 'Spaces that are never considered to be shared, never become shared'. They continued 'if the Temple's sole legacy is to reclaim this space for all it will nonetheless be a significant triumph. ${ }^{63}$ Although the choice of location was a risk it was one that ultimately paid off. As Till observes 'urban social environments and inhabited and formerly inhabited places - as simultaneously material, metaphorical and imaginative, experiential and perceptual - do not deny its residents the possibilities of care and healing' ${ }^{64}$ Kelly's fields would be completely reimagined. ${ }^{65}$

The Temple would be unlike the contentious bonfires, built and burned in the heart of working-class neighbourhoods; the commemorative parades performed along contested routes or the city's plantation walls, or the many memorials and murals narrating the experience of one community's suffering at the hands of another. It would not actively contribute to the territorialisation of space along political or religious lines, a process which Newman suggests works to tie people to the spaces they inhabit whilst providing dichotomous boundaries of inclusion and exclusion. ${ }^{66}$ It was devoid of the visible trappings of territoriality and identity that demarcates many interface communities such as flags, emblems and painted kerbstones. Its hillside and almost rural location meant that it was not a space which people encounter in their everyday lives, unlike many of the physical memorials and murals that adorn specific neighbourhoods and streetscapes. An estimated 60,000 participants had to make a conscious choice to visit the site, to climb a steep hill, effectively making a pilgrimage to the site itself. Significantly, and lending to the idea that the Temple might be viewed as some sort of countermonument, those who participated did not appear to bring with them any of the paraphernalia that might ordinarily be found at a bonfire or on a monument or mural-there were no national flags or banners, nor were there any visible divisive emblems or overtly political symbols or graffiti. 
The ephemeral nature of the structure was also significant in that participants were not given an opportunity to make a permanent change to the physicality of place. As Young notes: 'time mocks the rigidity of monuments, the presumptuous claim that in its materiality, a monument can be regarded as eternally true, a fixed star in the constellation of collective memory' ${ }^{67}$ Instead, their intervention was one that was momentary and fleeting. From the very outset, the understanding was that any inscription would only exist until the final burn. For one week only, participants could make their mark and record their message, safe in the knowledge that those narratives would be gone with the flames that would eventually engulf the structure. Those who added to the text that filled every surface on the Temple embraced the temporal nature of the moment as meaningful for how they wished to contribute to the memorial process. Unlike more traditional commemorative monuments fashioned in stone with their concretised narratives there for all to see, the Temple offered something fundamentally new. The comments were unguarded, instinctive and personal, despite the fact that they were etched onto an open and shared space.

\section{Remembering for everyone: A narrative open to interpretation}

In the Temple, an initiative which initially might be considered familiar (a bonfire) was overturned to become something novel. In anticipation of its arrival, a commentator observed: 'Bonfires are made by both sides of the community in Northern Ireland. This one is about something completely different, with no political motivations' ${ }^{68}$ This comment encapsulates part of the Temple's appeal to those who engaged with it. It was clearly something different, something unknown and unaligned with any specific ethno-nationalist group or tradition. It did not commemorative a singular event, person or tradition. It had a fluidity that somehow invited a multitude of experiences. This became clear when the project was opened to the public. Its 'power' or impact appeared to gain currency each day. Participants made a form of pilgrimage to the Temple 'not knowing what to do' and with very little instruction. They came from their own liminal spaces, with divergent narratives, experiences, losses and expectations. Volunteers offered participants small pieces of wood, leftover remnants of the building materials, on which to write messages or attach photos or meaningful paraphernalia. Throughout the week, thousands of people visited the structure turning it into a living, dynamic artefact.

For some, the Temple was about loss-all loss, irrespective of the context. The material pinned to or and words inscribed to the structure tells the stories of loved ones as family members or friends primarily 'Love you. Miss you mum', 'RIP Dad' 'I think about you every day' 'I hope you are lighting up the night sky'. It remembered those who had lost through conflict or through illness, through accidental death and through suicide. In a city where public, shared memorials are largely absent, and conflict losses are never to be found publicly remembered alongside other deaths, the Temple offered a radical departure for the public negotiation of loss, opening unprecedented possibilities for reflection and perhaps for mending division. It allowed individuals acknowledge their memories and to mourn in a public space. For Riceour, mourning is a form of reconciliation, an act that can lend to the renegotiation of divisive pasts. ${ }^{69}$ An outpouring of individual grief was momentarily captured and represented in a collective liminal and temporary space. Temple 'Guardians', described the people of the city as 'encumbered by the past' and viewed the project as an opportunity for the visitor to 'bring whatever is burdening you' to what she viewed as something hopeful. Via the burn, the Temple was seen as a means to unburden oneself. A witness to the events of Bloody Sunday (in which 13 civilians were fatally shot by the British Army during a civil rights march in the city in 1972), focused on the opportunity to transform the purpose of remembering: 'everyone has their own story to tell, piece of history to let go of. [The Temple] is not about forgetting, it's about remembering and letting go'.70 
Significantly, the Temple offered an opportunity to move away from the binary labels of victims and perpetrators, so often a source of conflict in the political landscapes of post-Agreement Northern Ireland. For others, the Temple acted as a vehicle through which to express narratives of the past but also hopes for the future. 'Dear universe please grant us a child' read one inscription. So many asked for an end to sickness, disease and addiction 'Please make my granda better', 'Let all my demons of the past go away', 'Heal me', Make our wee girl better'. Other messages aspired to a more hopeful future: 'Here's to a better future'. 'Love. Live a life you'll remember'. 'Let the past go', 'Life is precious-there is always hope'. For others still, the Temple was a place of reckoning and forgiveness 'Seamus (name changed) did not mean to do this-he just got lost', another message simply read 'I'm so sorry'. For the youngest participants, the Temple was simply a new place to play, discover and scribble on. By the end of the week, the emotion at the site was palpable and all 20,000 tickets for the final burn were very quickly allocated. As the Temple, and all the memories and mementoes attached to it, burned to the ground, the crowd applauded. A living, dynamic and public archive disappeared. David Best's Twitter feed revealed an overwhelming outpouring of support, gratitude and awe, pointing not just to the Temple's power, but also to its collectivizing, transformative properties. Local people took ownership of the experience and used a variety of hashtags to share their thoughts. In an analysis of tweets sent directly to Best, every single one registered a positive sentiment. Participants tweeted 'I love my Temple'; 'I love my city'; 'a spectacle that will stay with me'; 'Positive. Inclusive. Healing. Helping'; 'Healing Temple in Derry'; 'Temple built to burn away despair'. These tweets conveyed a sense of ownership and were significantly devoid of any mention of victimhood or ethno-nationalist tension.

\section{Conclusion: Liminal space and the creation of new spaces of remembrance and possibility}

So what can we learn from the Temple case study? This paper makes a number of significant contributions to our understanding of memory in the landscape and to the discipline of cultural geography more broadly. Drawing on Till's concepts of 'wounded cities', 'place-based care' and 'memorywork', this paper has explored the ways in which liminality can provide a novel and more nuanced way of thinking about the twin processes of remembrance and peacebuilding in deeply divided societies. Liminality, we suggest, perhaps affords more opportunities for flexible and transitional thinking in challenging environments. The fluidity of liminal space can offer an alternative way of remembering in cities where painful memories are closely linked to particular places.

For societies embroiled in navigating difficult and divisive pasts there is important learning in the ephemeral nature of Best's Temple. Many of Derry's residents engaged with the site precisely because of its temporal state. It bore witness to their memories and experiences in that particular moment but did not bind them to it. This is significant.Remembering, as Elizabeth Jenlin's important work reminds us, is not a linear or finite process; painful memories evolve and change. ${ }^{71}$ In the aftermath of conflict or a traumatic event, there is often as Edkins observes, an impulse to inscribe memory onto place. ${ }^{72}$ The words we use, the form we create and our hopes and aspirations for a site are concretised, but they sometimes change, or are deliberately changed. ${ }^{73}$ Participants came to the Temple knowing that whatever messages or artefacts they brought would ultimately be destroyed. The final burn would leave only scorched earth which would, through time, recover and heal. The end of the Temple's physicality could offer new beginnings. This powerful symbolism was not lost on those who participated. Unlike many physical memorial landscapes in public spaces across our towns and cities, which are subject to competing interpretations and multiple meanings, the narratives embedded in this fleeting structure could not be challenged, resisted, celebrated or manipulated over time.

Till suggests that in order to give and receive care in wounded cities 'people need to be recognized and recognize themselves in their social and physical environments....${ }^{74}$ Our cultural landscapes can 
reflect who we are and what we value. ${ }^{75}$ Too often, however, as Mitchell and many others have observed, they do not reflect the experiences, interpretations and histories of minority or marginalised groups in society. ${ }^{76}$ The Temple's 'success' could be attributed for the most part to Best's sustained and committed engagement with multiple groups within the city who were able to 'see themselves' in the structure and address their 'open wounds'. Our research revealed a collective sense of purpose, although it was unclear what the Temple would be and how people might choose to experience or understand it. This collectivising and multi-voice approach within memory-work is not always possible, yet its potential for healing is clear. ${ }^{77}$ In avoiding structuring a particular theme, Best and the Artichoke team opened the Temple up for everyone. Some of those who experienced the site on the night of the burn spoke of its power and of its perceived impact on both the city and its inhabitants. One participant tweeted 'David Best take a bow. You've brought spirituality to a place that needs a break from religion and politics'. Another wrote 'An awe inspiring spectacle and heart wrenching at the same time! And so it turned to ash'. Twitter users thanked Best for 'A very powerful experience' stating 'they've built something special in Derry/Londonderry'.

Beyond the burn, amongst the many conversations, the anecdotal responses and the large-scale reporting across regional and national outlets, it is difficult to qualify or capture the Temple's legacy. We would argue however that it contributed to the often elusive process of building peace. Best and the Artichoke team managed to create a space that temporarily allowed participants to come together on a huge scale to remember the past in an unprecedented way in the context of remembering in Northern Ireland. ${ }^{78}$ He was able to recreate the sense of hope that Johnson had observed in her reading of memory-work in Omagh in 2008, but on a larger scale and perhaps with less of the challenges that were to be powerfully overcome in order to create a collective memorial. ${ }^{79} \mathrm{In}$ providing a safe, public space unaligned to a specific community for the city's population to commemorate and acknowledge their respective losses, the Temple appeared to supersede and transform ethno-national and religious boundaries for a time. Its reimagining in a divided city was part of a belief that it could produce a dialectic that could potentially counter competing territorial ideologies and divisive cultural practices. Significantly, the organisers were concerned people would not participate. Yet in the words of a staffer, 'They did, over 60,000 people in a week and each one took that step on their own. Perhaps they didn't even know they were taking a step'. ${ }^{80}$

\section{Notes}

\footnotetext{
${ }^{1}$ S. Marschall, Landscape of Memory. Commemorative Monuments, Memorials and Public Statuary in Post-apartheid South-Africa (Brill, Leiden., 2010).; W.J., Neill, 'Return to Titanic and Lost in the Maze: The search for Representation of 'Post-conflict' Belfast', Space and Polity (2006) pp.109-120; K.E Till, The New Berlin (Minnesota, Minnesota Press., 2005). N.C Johnson, 'The contours of memory in post-conflict societies: Enacting public remembrance of the bomb in Omagh, Northern Ireland' cultural geographies, 19 (2009), pp. 237-258

${ }^{2}$ K. Brown, 'Commemoration as symbolic reparation: New narratives or spaces of conflict?' Human Rights Review 14 (2013), pp.273-289; B. Graham and Y. Whelan, 'The legacies of the dead: commemorating the Troubles in Northern Ireland' Environment and Planning D: Society and Space 25 (2007), pp.476-495.

${ }^{3}$ K.E Till , 'Wounded cities: Memory-work and a place-based ethics of care', Political Geography 31(2012), p. 7.

${ }^{4}$ J. E. Young 'The counter-monument: memory against itself in Germany today'. Critical Inquiry'18, no. 2 (1992), pp. 267-296.

5 Young, 'The counter-monument', p. 268.

${ }^{6}$ Phineas Harper, 'Let it burn: Temple in Derry, Northern Ireland by David Best/Artichoke' https://www.architecturalreview.com/today/let-it-burn-temple-in-derry-northern-ireland-by-david-best-/-artichoke/8681529.article accessed 10 January 2016

${ }^{7}$ Pierre Nora, 'Between Memory and History: Les Lieux de Mémoire’, Representations (1989), pp. 7-24.

8 Till, 'Wounded Cities', p. 7.

9 Till, 'Wounded Cities', p.7.
} 
${ }^{10}$ See for example S Mc.Dowell, 'Commemorating dead 'men': Gendering the past and present in post-conflict Northern Ireland'. Gender, Place and Culture 15, 4 (2008):335-54; E. Crooke 'Confronting a Troubled History: Which past in Northern Ireland's museums?. International Journal of Heritage Studies 1;7(2001):119-36.

${ }^{11}$ For more on the use of ethnography as a methodological approach within geographical research see S. Herbert, "For ethnography." Progress in human geography 24 no.4 (2000), pp. 550-568.

${ }^{12}$ M. Castells, Networks of outrage and hope: Social movements in the Internet age (John Wiley \& Sons, London., 2015).

${ }^{13}$ W.L Bennett, 'The personalisation of politics: Political identity, social media, and changing patterns of participation', The Annals of the American Academy of Political and Social Science 644 no 1 (2012), pp. 20-39.

${ }^{14}$ B. D Loader and Dan Mercea, eds. Social media and democracy: Innovations in participatory politics. (Routledge, London., 2012).

${ }^{15}$ Whiting, Anita, and David Williams, 'Why people use social media: a uses and gratifications approach', Qualitative Market Research: An International Journal 16 (2013), pp. 62-369.

${ }^{16}$ Johnson, 'The contours of memory', p 240.

${ }^{17}$ E. Aronoff and Y. Aronoff ,'Bordering on peace: Spatial narratives of border crossings between Israel, Jordan and Egypt' In C. Loeb and A. Luescher eds The Design of Frontier Space: Control and Ambiguity (Routledge, New York., 2016), pp 129-156.

${ }^{18}$ Cited in L. Schirch, Ritual and Symbol in Peacebuilding (Kumarian Press, 2005).

${ }^{19}$ Schirch, 'Ritual and Symbol', p. 530,

${ }^{20}$ D. Moran 'Between outside and inside? Prison visiting rooms as liminal carceral spaces' GeoJournal, 78 (2013), pp.339-351; N. Gill, Carceral spaces: Mobility and agency in imprisonment and migrant detention (Routledge, London., 2016). Madge, C. and H. O'Connor, Mothers in the making? Exploring liminality in cyber/space. Transactions of the Institute of British Geographers, 3 (2010), pp.83-97. H. Matthews, 'The street as a liminal space'. In Children in the city: Home, neighbourhood and community Routledge London (2007) pp. 101-117). Wood et al. 2016; Howitt 2001; B. Wood (2012) Crafted within liminal spaces: Young people's everyday politics, Political Geography 31 (2012), $337-346$.

${ }^{21}$ Till, 'Wounded Cities,' p. 3.

${ }^{22}$ K.K. Chen, Enabling creative chaos: The organisation behind the Burning Man event (University of Chicago Press, Chicago., 2009).

${ }^{23}$ D.L. Bottorff, 'Emerging Influence of Transmodernism and Transpersonal Psychology Reflected in Rising Popularity of Transformational Festivals', Journal of Spirituality in Mental Health, 17 (2015), pp. 50-74.

${ }^{24}$ Bottorff, 'Emerging Influence', 87

${ }^{25}$ K.K. Chen, 'Lessons for creative cities from Burning Man: How organisations can sustain and disseminate a creative context'. City, Culture and Society, 2 (2011), pp.93-100.

${ }^{26}$ See Lee Gilmore, Theater in a crowded fire: Ritual and spirituality at Burning Man. Vol. 1. (University of California Press, 2010)., and L. Gilmore, and M. Van Proyen, AfterBurn: Reflections on burning man. (UNM Press, 2005).

${ }^{27}$ L. Van Meter,The Temples at Burning Man (2008) available at https://www.inter-disciplinary.net/ptb/mso/dd/dd5/VanMeter\%20paper.pdf accessed 16th December 2017.

${ }^{28}$ D. Best Interview with San Francisco Museum of Modern Art 2012 available at https://www.sfmoma.org/watch/davidbest-is-a-burning-man/ accessed 30 June 2016.

${ }^{29}$ K. Bateman, Symbol-making in Bereavement: The Temples at Burning Man, (2014) p.8 available at http://www.interdisciplinary.net/probing-the-boundaries/wp-content/uploads/2013/10/batemanddpaper.pdf

${ }^{30}$ Bowlby 1961 cited in Bateman 2014

${ }^{31}$ Freud 1959 cited in Bateman 2014

${ }^{32}$ Crooke, 2017 Memory politics and material culture: Display in the memorial museum Memory Studies OnlineFirst

${ }^{33}$ Bateman,'Symbol-making', p 9

${ }^{34}$ M. Rodriguez "“Long Gone Hippies in the Desert": Counterculture and "Radical Self-Reliance” at Burning Man." M/C Journal 17.6 (2014), p 3.

35 Till, 'Wounded Cities', p.10.

36 Till, 'Wounded Cities', p. 10.

${ }^{37}$ After the Flight of the Earls in the early 1600s the Crown asked twelve London companies to finance the confiscation of land in the province of Ulster in Ireland. They became known as the Honorable the Irish Society and were responsible for the plantation in the north of Ireland. See T.W Moody The Londonderry Plantation 1609-41. The City of London and the Plantation of Ulster (Belfast: William Mullan, 1939).

${ }^{38}$ See S. Prince and G. Warner Belfast and Derry in Revolt: A New History of the Start of the Troubles. (Irish Academic Press 2012)., B. Conway, 'Active remembering, selective forgetting, and collective identity: The case of Bloody Sunday', Identity: An International Journal of Theory and Research, 3(2003), pp.305-323. G. Dawson 'Trauma, Place and the Politics of Memory: Bloody Sunday, Derry 1972-2004', History Workshop Journal 59 (2005) pp, 151-178.

39 J. Santino, "Light up the sky: Halloween bonfires and cultural hegemony in Northern Ireland." Western folklore 55.3 (1996): 213-231.

${ }^{40}$ N. Jarman, Material Cultures: Parades and Visual Displays in Northern Ireland (Berg, London., 1997) 
${ }^{41}$ Hocking, Bree 'A bit of burning man comes to Derry' US News and World Report https://www.usnews.com/opinion/blogs/opinion-blog/2015/03/17/can-northern-ireland-burning-man-ritual-turn-sectarianism-on-its-head accessed 20 November 2016

${ }^{42}$ S. Cohen, "Winning while losing: The Apprentice Boys of Derry walk their beat." Political Geography 26.8 (2007), pp.951-967.

${ }^{43}$ K. Bennhold, 'Healing fire in Londonderry: The Temple that was built to burn', The New York Times 27 March 2015.

${ }^{44}$ Online comments on the Derry Journal

${ }^{45}$ Best, 2015.

46 Tweet from participant.

${ }^{47}$ D. Rieff, In praise of forgetting: Historical memory and its ironies. (Yale University Press, Yale., 2016).

${ }^{48}$ Rieff, In praise of forgetting, p. 45.

${ }^{49} \mathrm{~S}$. McDowell and C. Switzer, 'Violence and the Vernacular: Conflict, Commemoration, and Rebuilding in the Urban Context' In Buildings \& Landscapes: Journal of the Vernacular Architecture Forum 18, 2 (2011): 82-104.

${ }^{50}$ Graham and Whelan, 'The legacies of the dead', p. 482

${ }^{51}$ Marschall, Landscape of Memory p.5

${ }^{52} \mathrm{~S}$ McDowell and M Braniff Commemoration as Conflict: Space, Memory and Identity in Peace Processes (Macmillan, London., 2014).

${ }^{53}$ See in particular: Leib, Jonathan I. "Separate times, shared spaces: Arthur Ashe, Monument Avenue and the politics of Richmond, Virginia's symbolic landscape." cultural geographies 9, no. 3 (2002): 286-312. Alderman, Derek H., and Joshua FJ Inwood. "Landscapes of memory and socially just futures." The Wiley-Blackwell companion to cultural geography (2013): 186-197.

${ }^{54}$ K. McEvoy and H. Conway, 'The Dead, the Law, and the Politics of the Past', Journal of law and society, 31(2004), pp.539-562.

${ }_{55}$ J. Gillis, Commemorations: The politics of national identity (Princeton University Press, Princeton., 1996).

${ }^{56}$ Arts Council Northern Ireland 'Campaign to bring Burning Man to Derry' 22 September 2014. http://artscouncilni.org/news/campaign-launched-to-bring-burning-man-project-to-derry-londonderry accessed 09 March 2016.

${ }^{57}$ John Peto, 'Temple will belong to the city'9 March 2015 available at http://templederry-londonderry.com/blog/templewill-belong-to-the-city accessed 10 March 2016.

${ }^{58}$ Ken Harland "Violent youth culture in Northern Ireland: Young men, violence, and the challenges of peacebuilding." Youth \& Society 43, no. 2 (2011), pp. 414-432.

${ }^{59}$ Ken Harland, and Sam McCready. "Rough Justice: considerations on the role of violence, masculinity, and the alienation of young men in communities and peacebuilding processes in Northern Ireland." Youth Justice 14, no. 3 (2014), pp. 269-283.

${ }^{60}$ Harland and McCready, 'Rough Justice', p. 270.

${ }^{61}$ C. Rose 'Sacredness, Solemnity and Memory 15 March 2015 available at http://templederry-londonderry.com/blog/sacredness-solemnity-and-memory accessed 10 September 2016.

${ }^{62}$ Harper, 'Let it burn' p.3.

${ }^{63}$ Harper, 'Let it burn', p.2.

64 Till, 'Wounded Cities', p.7.

${ }^{65}$ Till, 'Wounded Cities', p. 7.

${ }^{66}$ Newman, David. "Real spaces, symbolic spaces: Interrelated notions of territory in the Arab-Israeli conflict." In Diehl, P (eds) A road map to war: Territorial dimensions of international conflict (1999): 3-34.

${ }^{67}$ Young, 'The counter-monument' p.11.

${ }^{68}$ Online comment in response to an article on the Temple coming to Derry, $26^{\text {th }}$ October 2014.

${ }^{69}$ P. Ricoeur, Memory, history, forgetting. (University of Chicago Press, 2004).

${ }^{70}$ Online comment on the Temple website

${ }^{71}$ E. Jenlin State Repression and the Labors of Memory (Minnesota, University of Minnesota Press., 2003).

72 J Edkins, Trauma and the Memory of Politics (Cambridge, Cambridge University Press.,2004).

${ }^{73}$ S Marshall, 'Places of Memory' 2003.

74 Till, 'Wounded Cities', p. 9.

${ }^{75}$ D.E Cosgrove Social Formation and Symbolic Landscapes (University of Wisconsin. London.1984).

${ }^{76}$ D. Mitchell, 'Just landscapes or Landscapes of Social Justice?' Progress in Human Geography 27, 6 (2003) pp. 787796. Also see for example Derek Alderman and Joshua Inwood's important work on the spatial injustices at work in the commemoration of Martin Luther King in the United States. D Alderman and J. Inwood, 'Street-naming and the politics of belonging: Spatial injustices in the Toponymic commemoration of Martin Luther King', Social and Cultural Geography, 13 (2003),pp. 211-233.

${ }^{77}$ Katherine K. Chen "Plan your Burn, Burn your Plan": How Decentralization, Storytelling, and Communification Can Support Participatory Practices, The Sociological Quarterly, 57:1 (2016 ) 71-97.

${ }^{78}$ McDowell and Braniff, Commemoration as Conflict, p.49.

${ }^{79}$ Johnson, 'The contours of Memory', p.240. 
${ }^{80}$ One small step in the same direction Josh Lease 21 April 2015 https://journal.burningman.org/2015/04/burningman-arts/global-art/the-derry-temple-a-small-step-in-the-same-direction/ 